UDC 663.253.012.1; 663.81.012.1

COBISS.SR-ID: 220358668

Original research paper

Acta Agriculturae Serbica, Vol. XX, 40 (2015); 137-144

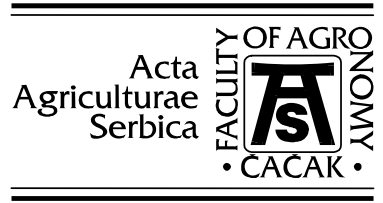

\title{
Quality of fruit nectars and wines on the local market: harmonization with quality standards
}

\author{
Vesna Đurović *, Radmila Ilić \\ University of Kragujevac, Faculty of Agronomy in Čačak, Cara Dušana 34, \\ 32000 Čačak, Serbia \\ djurovicvesna@yahoo.com
}

\begin{abstract}
The goal of this study was to determine whether the quality of fruit nectars and wines available on the local market is in accordance with the quality prescribed by the Rulebook. The research involves analysis of blueberry, strawberry, peach, apple and orange fruit nectars from two companies $(\mathrm{C} 1$ and $\mathrm{C} 2$ ), and samples of red wines from three wineries (W1-3). The following quality parameters were determined: soluble solids content (\% Brix), actual acidity $(\mathrm{pH})$ and titratable acidity in the nectars, and actual acidity $(\mathrm{pH})$ and titratable acidity in the wines.

All samples of fruit nectars met the prescribed \% Brix requirements. Titratable acidity, expressed in $\mathrm{g} \mathrm{dm}^{-3}$ citric acid, in $\mathrm{C} 1$ blueberry and strawberry nectars deviated from the values laid down in Rulebook 2 (Rulebook on the Quality of Fruit Juices, Concentrated Fruit Juices, Fruit Juice Powder, Fruit Nectars and Related Products- Official Gazette of RS Issue No. 27/2010). Deviations were detected in C2 orange nectar. The total acid content in the analyzed wine samples, expressed in $\mathrm{g} \mathrm{dm}^{-3}$ of tartaric acid, corresponded to the values prescribed in Rulebook 1 (Rulebook on Quality and Other Requirements for Wine - Official Gazette Issues Nos. 54/99 and 39/2002, Official Gazette Issue No. 56/2003 - other Rulebook and Official Gazette Issue No. 87/2011 - other Rulebook and 26/2015 - other Rulebook).
\end{abstract}

Keywords: total acids, fruit nectar, wine 


\section{Introduction}

The processing of different types of fruit juices has been known since ancient times. Fruit juices are healthy, delicious and refreshing drinks, which are used as a food supplement. Fruit juices provide the fastest supply of vitamins, minerals and enzymes for the human body (Jensen 2002), and are also a good source of energy since they are full of fructose (Millidge 2003). Fruit juices are made from fresh or frozen healthy fruits. Preference is given to fruits that are not sold for fresh consumption or for off-season processing, which is of economic significance. Juices are usually produced from apples, as the most widely cultivated fruit crop, as well as from pears, peaches, cherries, blackberries, raspberries, plums, grapes and other fruits (Niketić-Aleksić 1988). They are produced from a single fruit or from a blend of fruits (Niketić-Aleksić 1988).

Fruit juice production is a highly intensive and promising industry worldwide. According to the European Fruit Juice Association (AIJN), in the European Union about 11,500 million liters of fruit juice are produced annually (Anonymous 1). The biggest producers are Germany (with an annual production of 2,800 million liters), France $(1,600)$, United Kingdom $(1,400)$ and Spain $(1,300)$. Serbia produces around 230 million liters of fruit juice (Anonymous 2).

Fruit juices contain organic acids as natural components of fruits being processed. Also, organic acids can be added during the technological processing, as antioxidants or preservatives (Rulebook 2). The composition of acids depends on the type of fruit, the most common including: malic acid, citric acid and tartaric acid, followed by oxalic acid, salicylic acid and acetic acid. Some of them are essential for organoleptic properties (taste, color stability) and quality. Moreover, some of them are indicators of different processes that occur during the production and storage of fruit juices (such as ripening and microbial spoilage). Determination of organic acids in fruit juices is important for the control of fruit juice, and can be used to verify the authenticity of a fruit juice (Niketić-Aleksić 1988).

Organic acids provide the tart fruit flavor and slow the action of bacteria by lowering the $\mathrm{pH}$ value of the product. There is also evidence that acids from fruits and sweets have an impact on the oral microflora, both citric and malic acid inhibiting oral microorganisms (Grenby and Saldanha 1988). However, some acids from fruit juices may negatively affect the tooth enamel (Meurman et al. 1987).

According to the Rulebook, the total acid content is expressed on the basis of the dominant acid. In that case, for fruit concentrates and nectars of apples, cherries, blueberries and strawberries, total acidity is expressed in terms of citric acid.

The wine is an agri-food product obtained through full or partial alcohol fermentation of pomace or fresh grape must suitable for processing into wine (Rulebook 1). Organoleptic qualities, healing properties, antitoxicity, 
bactericidal, antianaphylacticity and other features depend on the chemical composition. Physico-chemical methods determine the composition of certain ingredients of wine, as defined by the Rulebook on Wine Quality. Total world wine production in 2002-2011 was 27,948,486 t (average), and in 2011 it amounted to 29,374,740 t (FAOSTAT 2013). According to data from the National Statistics Office, the average wine production in Serbia for the period 2006-2011 was 182,379 t (Anonymous 2012.)

\section{Materials and methods}

Samples of fruit nectars (blueberry, strawberry, apple, peach and orange) and samples of red wines were purchased on the local market. The following parameters were determined: soluble solids content (\% Brix), actual acidity $(\mathrm{pH})$ and titratable acidity in fruit nectars, $\mathrm{pH}$ and titratable acidity in the wines. Soluble solids content (AOAC 1995) was determined by an MT 032 ATC refractometer (Turon et C., Forli, Italy). Readings of $\mathrm{pH}$ were obtained with a $\mathrm{pH}$ meter (Consort-C860) by immersing the combined electrode into the sample and reading the values (AOAC 1995). Potentiometric titration is a method applicable to the determination of titratable acidity in fruits, vegetables and their processed products (AOAC 1995).

Determination of titratable acidity was based on the potentiometric titration standard solution of $\mathrm{NaOH}$, for fruit nectars.

A glass pipette was used to measure a $10 \mathrm{~cm}^{3}$ aliquot of a nectar sample, supplemented with distilled water to $50 \mathrm{~cm}^{3}$ and heated on a hot plate to boiling point. After cooling, the sample cup was placed on a magnetic stirrer, a magnetic core was inserted, and the mixer was turned on. The combined glass electrode was immersed in the test solution, previously attached to a $\mathrm{pH}$ meter. The $\mathrm{pH}$ meter was used to measure the initial $\mathrm{pH}$ value, and the standard pattern was titrated with $\mathrm{NaOH}$ solution, $\mathrm{c}(\mathrm{NaOH})=0.1 \mathrm{~mol} \mathrm{dm}^{-3}$, by addition of a titrant of a certain volume to a burette, with simultaneous sensing of $\mathrm{pH}$. Titratable acidity in the nectar was calculated by the following equation:

$$
\mathrm{m}=1 / 3 \cdot \mathrm{c}(\mathrm{NaOH}) \cdot \mathrm{V}(\mathrm{NaOH}) \cdot \mathrm{M}\left(\mathrm{C}_{3} \mathrm{H}_{5}(\mathrm{COOH})_{3}\right) \cdot \mathrm{q}
$$

Where:

c $(\mathrm{NaOH})$ - the concentration of sodium hydroxide solution, $\mathrm{mol} \mathrm{dm}^{-3}$

$\mathrm{q}$ - an aliquot part (the ratio of the total volume and analyzed 100).

Determination of titratable acidity was based on $\mathrm{KOH}$ as the potentiometric titration standard solution for wines.

A $50 \mathrm{~cm}^{3}$ aliquot of a wine sample was measured in a glass pipette, a magnetic core was placed, and the combined $\mathrm{pH}$ electrode was immersed in the solution for analysis. Titration was carried out by the standard aqueous solution of $\mathrm{KOH}$ of $0.25 \mathrm{~mol} \mathrm{dm}^{-3}$ concentration, and stirring was performed by a magnetic stirrer. The titration solution was added to certain aliquots to record the pH value (Rajković and Novaković 2005). Potassium hydroxide is consumed in 
the neutralization of all substances in the wine which have an acidic character, and the amount of total acids in the wine is expressed as the mass of tartaric acid, since this acid is one of the most important for wine quality (Jović 2003, Durliat et al. 2005). Total acid content expressed in $\mathrm{g} \mathrm{dm}^{-3}$ of tartaric acid was obtained using the following equation (Rajković and Sredović 2009):

$$
\mathrm{m}\left(\mathrm{H}_{2} \mathrm{C}_{4} \mathrm{H}_{4} \mathrm{O}_{6}\right)=1 / 2 \cdot \mathrm{c}(\mathrm{KOH}) \cdot \mathrm{V}(\mathrm{KOH}) \cdot \mathrm{M}\left(\mathrm{H}_{2} \mathrm{C}_{4} \mathrm{H}_{4} \mathrm{O}_{6}\right) \cdot 20
$$

the 20-aliquot part (the ratio of total and analyzed volume) of tartaric acid content is expressed in $\mathrm{g} \mathrm{dm}^{-3}$.

The endpoint of a titration or consumption of a titrant can be determined in two ways. The Rulebook regulates the calculation of total acid content in fruit nectars according to the volume of the titration agent consumed until the $\mathrm{pH}$ value of the solution reaches 8.1 (the moment when phenolphthalein changes color with conventional titration). The other method uses the peak in the differential titration curve to determine the volume of titration i.e. the endpoint of titration. The total acid content in wines is calculated according to the volume of titration agent consumed until the $\mathrm{pH}$ of the solution reaches 7 .

The results obtained by potentiometric titration are processed using the Origin 6.1 mathematical data processing software. Information on the volume of titration agent consumed is used in the conversion formulas. The value of titratable acidity is compared with values laid down in the Rulebook on the Quality of Fruit Juices, Concentrated Fruit Juices, Fruit Nectar Powder, Fruit Nectars and Related Products (Official Gazette of the RS, Issue No. 27/2010) and the Rulebook on the Procedure of Production and Quality of Table Wines and Wines with Geographical Indications (Official Gazette of the RS, Issue No. $87 / 11)$. The data on wine quality were subjected to statistical analysis using t-test (Stanković 1990).

\section{Results and Discussion}

One of the two analyzed samples of $\mathrm{C} 1$ blueberry nectars had much lower values $\left(4.83 \mathrm{~g} \mathrm{dm}^{-3}\right)$ of total acids compared to Rulebook 2 (10.7-14.5). The same case was strawberry nectars $\left(4.608 \mathrm{~g} \mathrm{dm}^{-3}\right)$, while apple and peach nectars were in correlation with Rulebook 2 (Table 1). Samples of C2 nectars showed exceptions for orange nectar $\left(4.987 \mathrm{~g} \mathrm{dm}^{-3}\right)$. Similar results $\left(4 \mathrm{~g} \mathrm{dm}^{-3}\right)$ were found by Leahu et al. (2013) for orange juice. The tested samples of both producers fulfilled the quality parameter given through soluble solids content (\% Brix). Brix is defined as the percentage of dissolved sugar in the solution and is expressed in \% Brix (Shachman 2005). The relationship between \% Brix and the percentage of sugar and acids can be considered a parameter of juice composition and an indicator of adulteration (Singhal, 2001). The Rulebook on the Quality of 
Fruit Juices allows addition of water and sugar during the process, and citric acid is typically added to mask the addition of sugar (Voldrich et al. 2002).

Nectars from apples and peaches are investigated, and parameters were in accordance with Rulebook 2 . These results are probably the consequence of domestic, cheaper processing inputs. However, oranges and blueberries are at a high rate input, and adulteration is possible. Consumers should bear this in mind when choosing a product to buy.

Table 1. Total acids in fruit nectars, expressed through anhydrous citric acid $\left(\mathrm{g} \mathrm{dm}^{-3}\right)$

\begin{tabular}{|c|c|c|c|c|c|}
\hline Sample & $\mathrm{pH}$ & $\%$ Brix & $\begin{array}{l}\text { \% Brix, } \\
\text { Rulebook } \\
2\end{array}$ & $\begin{array}{l}\text { TA, g dm }{ }^{-3} \\
\mathrm{pH} 8.1\end{array}$ & $\begin{array}{l}\mathrm{TA}, \mathrm{g} \mathrm{dm} \\
\text { Rulebook } 2\end{array}$ \\
\hline Blueberry I & 3.50 & 10.6 & 8.5 & $4.832^{*}$ & $10.7-14.5$ \\
\hline Strawberry I & 3.30 & 10.8 & 6.3 & $4.608 *$ & $5.1-11.5$ \\
\hline Apple I & 3.26 & 10.8 & 10.0 & 4.704 & $2.2-7.5$ \\
\hline Peach I & 3.29 & 10.2 & 9.0 & 4.544 & $3.2-8.0$ \\
\hline Orange II & 3.60 & 10.8 & 10.0 & $4.987 *$ & $5.8-15.4$ \\
\hline Blueberry I & 3.31 & 10.8 & 8.5 & 7.420 & $10.7-14.5$ \\
\hline Orange I & 3.60 & 10.6 & 10.0 & 5.946 & $5.8-15.4$ \\
\hline Peach II & 3.54 & 10.4 & 9.0 & 5.946 & $3.2-8.0$ \\
\hline
\end{tabular}
$\mathrm{dm}^{-3}$ )

TA- Total acids (Titratable acidity at $\mathrm{pH} 8.1$ ) was expressed through anhydrous citric acid (g

*Values that are not in accordance with Rulebook 2

Table 2. Total acids in wine, expressed as tartaric acid $\mathrm{g} \mathrm{dm}^{-3}$

\begin{tabular}{cccc}
\hline Sample wines & $\mathrm{pH}$ & $\begin{array}{l}\mathrm{m}\left(\mathrm{H}_{2} \mathrm{C}_{4} \mathrm{H}_{4} \mathrm{O}_{6}\right), \mathrm{g} \mathrm{dm}^{-3}, \mathrm{pH} \\
7\end{array}$ & $\begin{array}{l}\text { TA (min. } \\
\text { value, } \\
\text { Rulebook 1) }\end{array}$ \\
\hline W1 & 3.30 & 4.87 & 4.50 \\
W2 & 3.10 & 5.51 & 4.50 \\
W3 & 3.17 & 5.25 & 4.50 \\
\hline
\end{tabular}

The total acids content in red wines was the legal framework for impairment of the Rulebook on the Quality of Wine, which stipulates a minimum total acids content $\left(4.50 \mathrm{~g} \mathrm{dm}^{-3}\right)$, expressed as tartaric acid and is consistent with studies of other authors (Rajković and Sredojević 2009). For titratable acidity of less than 4 $\mathrm{g} \mathrm{dm}^{-3}$, the origin of wine is questioned i.e. it is suspected that during wine making there might have been some illegal action (Daničić 1984). Sample W2 has the lowest $\mathrm{pH}$ and the highest value of total acids, and W1samples had the smallest total acid content (Table 2). The measured $\mathrm{pH}$ of the tested wines was 
within the literature values. The $\mathrm{t}$-statistics $\left(\mathrm{t}_{\mathrm{sample}}=3.8213\right.$ and $\mathrm{t}_{0.05}=4.303$ and $\mathrm{t}_{0.01}=9.925$ ) showed that the average content of total acids in wine samples was not statistically different from the values given in Rulebook. This research revealed that the quality of analyzed wines is uniform and that they are harmonized with quality standards.

\section{References}

AIJN code of practice for the evaluation of fruit and vegetable juices (1996): The Association of the Industry of Juices and Nectars from Fruits and Vegetables of the European Economic Community, Brussels, permanent update.

Anonymous 1 www.aijn.org

Anonymous 2 www.pks.rs

Anonymous 3 www.rzs.stat.gov.rs

A O A C 1995. Official Methods of Analysis (16 th ed.). Washington, DC. Association of Analytical Chemists Official.

Daničić M. (1984): Wine Technology - Lab. Faculty of Agriculture, Belgrade-Zemun (in Serbian).

Transfer E., Toso S., Daniel S.F., Zelano V., and Ginepro M. (2004): Acid-Base Chemistry of Red Wine: Analytical Multi-Technique Characterisation and Chemical Equilibrium-Based Modelling, Analytica Chimica Acta, 507, pp. 263-273

F A O S T A T(2013): www.faostat.fao.org

Grenby T. H., and Saldanha M.G. (1988): Comparison of lycasin versus sucrose sweets and demineralisation studies of human enamel and hydroxylapatite. Caries Research 22, 269-275.

Durliat H., and Comtat M. (2005): Critical Evaluation of potentiometric titrations Redox in Enology, Analytica Chimica Acta, 545 pp. 173-181.

Jensen B. (2002): Treatment juices, Mosaic books, Zagreb

Leahu A., Damian C., Oroian M., Ropciuc S. (2013): Physico-chemical parameters of fruit juices evolution during storage, Stefan cel Mare University of Suceava, Romania.

Rajković M. B., and Novaković I. D. (2005): Practicum in analytical chemistry - classical methods, Faculty of Agriculture, Zemun,

Meurman J.H., Rytomaa I., Kari K., Laakso T., and Murtomaa H. (1987): Salivary $\mathrm{pH}$ and glucose B. Jensen after consuming various beverages, including sugar-containing drinks. Caries Research 21, 353-359.

Millidge J. (2003): Juices for energy and revitalization, U: Preparation of juices manual, Publisher Veble commerce, Zagreb, 40-44.

Rajković M. B., and Sredović I. D. (2009): The determination of total titratable acidy and tannins in red wine, Journal of Agricultural Sciences, Vol. 54, No. 3, Pages 223-246

Niketić-Aleksić G. (1988): Technology of fruit and vegetables. Belgrade: Faculty of Agriculture 
Rulebook 1. Pravilnik o kvalitetu i drugim zahtevima za vino („Sl. list SRJ”, br. 54/99 i 39/2002, „Sl. list SCG”, br. 56/2003 - dr. pravilnik i „Sl. glasnik RS", br. 87/2011 - dr. pravilnik i 26/2015 - dr. pravilnik)

Rulebook 2. Pravilnik o kvalitetu voćnih sokova, koncentrisanih voćnih sokova, voćnih sokova u prahu, voćnih nektara i srodnih proizvoda (,Sl. Glasnik RS“, br. 27/2010)

Jović S ., (2003): Organic acids in wine, Wine Journal, 6 Teagraf, Belgrade.

Shachman M. (2005): The Soft drinks Companion, A Technical Handbook for the beverage industry, CRC Press.

Stanković J., Lakić N., Ralević-Ljubanović I. (1990): Zbirka zadataka iz eksperimentalne statistike, Poljoprivredni Fakultet, Beograd

Voldrich. M., Scully P., Kvasnicka F., Cuhra P., and Kubik M. (2002): Authenticity of 100\% Orange Juice in the Czech Market in 1996-2001, Journal of Food Science, 20 (2): 83-88 


\title{
KVALITET VOĆNIH NEKTARA I VINA SA LOKALNOG TRŽIŠTA: USAGLAŠENOST SA PRAVILNIKOM O KVALITETU
}

\author{
Vesna Đurović *, Radmila Ilić \\ Univerzitet u Kragujevcu, Agronomski fakultet u Čačku, Cara Dušana 34, \\ 32000 Čačak, Srbija \\ djurovicvesna@yahoo.com
}

\begin{abstract}
Rezime
Cilj ovog istraživanja bio je da u slučajno odabranim uzorcima voćnog nektara i vina iz maloprodajnih trgovinskih objekata utvrdi kvalitet prema zadatim standardima o kvalitetu propisanim Pravilnicima. Analizom su obuhvaćeni voćni nektari borovnice, jagode, breskve, jabuke i narandže, dva proizvođača (C1 i C2), kao i crvenih vina iz tri vinarije (W1-3). Kao parametri kvaliteta određivani su: sadržaj rastvorljive suve materija (\% Brix), realna kiselost $(\mathrm{pH})$ i titraciona kiselost u nektarima, kao i realna kiselost $(\mathrm{pH}) \mathrm{i}$ titrataciona kiselost $u$ vinima.

Svi uzorci voćnih nektara zadovoljili su propisane vrednosti \% Brix-a zadate Pravilnikom. Titrataciona kiselost, izražena kao anhidrovana limunska kiselina, $\mathrm{g} \mathrm{dm}^{-3}, \mathrm{u}$ nektaru borovnice i jagode $\mathrm{C} 1$ odstupala je od vrednosti zadatih Pravilnikom 2 (Pravilnik o kvalitetu voćnih sokova, koncentrisanih voćnih sokova, voćnih sokova u prahu, voćnih nektara i srodnih proizvoda -"Sl. glasnik RS ", br. 27/2010). Odstupanja su utvrđena i u uzorku nektara C2 od narandže. U svim ispitivanim nektarima jabuke i breskve nije bilo odstupanja. Sadržaj ukupnih kiselina u analiziranim uzorcima vina, izražen u $\mathrm{g} \mathrm{dm}^{-3}$ vinske kiseline, odgovara vrednostima propisanim Pravilnikom 1 (Pravilnik o kvalitetu i drugim zahtevima za vino („Sl. list SRJ”, br. 54/99 i 39/2002, „Sl. list SCG”, br. 56/2003 - dr. pravilnik i „Sl. glasnik RS”, br. 87/2011 - dr. pravilnik i 26/2015 - dr. pravilnik).
\end{abstract}

Ključne reči: ukupne kiseline, voćni nektar, vina. 